\title{
PENGALAMAN RUANG MELALUI LIMA INDERA
}

\author{
Anita Hartati ${ }^{1)}$, Agustinus Sutanto ${ }^{21}$ \\ 1) Program Studi S1 Arsitektur, Fakultas Teknik, Universitas Tarumanagara, anitajayadi95@gmail.com \\ 2) Program Studi S1 Arsitektur, Fakultas Teknik, Universitas Tarumanagara, afirawiniera@gmail.com
}

\begin{abstract}
Abstrak
Jakarta, sang metropolis, saat ini adalah tempat bernaung bagi 10 juta penduduk Indonesia. Sebagai pusat ekonomi dan pemerintahan, Jakarta menarik banyak perhatian orang di luar kota untuk datang dan menetap di dalamnya sehingga membuat kota ini begitu padat. Selain padat akan penduduk, Jakarta juga padat akan bangunan, kendaraan dan polusi udara. Lingkungan seperti ini membuat penduduknya jarang merasa nyaman. Ditambah dengan masalah kehidupan pribadi membuat beban berat pada kondisi psikologis manusianya.Tidak heran jika penduduk kota Jakarta akrab dengan yang namanya stres. Manusia menggunakan lima indera sebagai alat untuk mengenal dunia. Mata untuk melihat, hidung untuk bernapas, telinga untuk mendengar, lidah untuk mengecap dan kulit untuk meraba. Saat ini di kota Jakarta kelima indera ini tidak lagi di stimulasi dengan pengalaman yang membuat nyaman. Sebut saja kebisingan dari klakson kendaraan yang memenuhi jalanan sehingga memekakkan telinga juga polusi udara yang penduduk Jakarta hirup setiap harinya. Untuk itu penulis mengkaji dan menganalis mengenai arsitektur dan interior yang dapat membuat manusia merasa nyaman. Sebagai tempat wisata Five Senses Experience ingin memberikan suatu pengalaman ruang melalui lima indera yang berbeda dari kehdupan sehari-hari di Jakarta. Melalui desain program wisata yang berupa perjalanan spiritual, tempat wisata ini diharapkan dapat menjadi alat coping stres bagi para pengunjung sehingga pikiran menjadi tenang dan damai.
\end{abstract}

Kata kunci: lima indera, pengalaman, spiritual, stres, wisata

\begin{abstract}
Jakarta, the metropolitan, is now a shelter for 10 millions people in Indonesia. As an economic and goverment center, Jakarta enticing many people who lives outside the city to visit and dwell in it that makes the city highly dense.Besides of the population density, Jakarta is full of building, vehicles and air polution. People finds it rare to be comfortable living in this kind of environment. Coupled with the problem of personal life which makes a heavy burden on the psychological condition of human beings. No wonder if the residents of Jakarta are familiar with stress. Human uses five senses as a tool to identify the world. Eyes to see, nose to breath, ears to hear, toungue to taste, and skin to touch. These days in Jakara, the senses are not stimulated by good environment. Mention the loud noise from vehicle's horn that filled the streets and the contaminated air which Jakarta's residents inhale everyday. Because of the problem, the author evaluated and analyse about architecture and interior in order to create comfort for human. As a tourism spot, Five Senses Experience Space wants to provide a different experience of space through five senses from daily life in Jakarta. With the tourism program design in the form of spiritual journey, this place is expected to be a coping stress tool for the visitor's mind to become tranquil and peaceful.
\end{abstract}

Keywords: experience, five senses, spiritual, stress, tourism

\section{PENDAHULUAN}

Jakarta merupakan kota terbesar di Indonesia. Dengan luas 661,52 m2 kota ini menampung 10.199.700 jiwa di dalamnya. Selain menjadi yang terbesar, Jakarta juga menjadi kota yang terpadat, terpenting dan tersibuk di Indonesia. Penting karena berbagai peran yang dimiliki oleh Jakarta, diantaranya; menjadi ibukota negara, pusat pemerintahan, pusat perdagangan, 
pusat pembangunan dan pusat pariwisata. Dengan andilnya dalam berbagai sektor, Jakarta menjelma menjadi kota metropolis dan menjadi induk bagi kota-kota di sekitarnya (Bogor, Depok, Tangerang, Bekasi).

Branding kota Jakarta yang kuat membuat banyak orang tertarik berkunjung ke Jakarta. Direktur Perencanaan dan Pengembangan Badan Pengelola Transportasi Jakarta (BPTJ) mengatakan, jumlah pergerakan orang dari dan ke Jakarta mencapai 47,5 juta setiap harinya. Pergerakan tersebut ditempuh dengan berbagai cara, ada yang menggunakan transportasi umum, seperti commuter line, kereta jarak jauh, busway hingga kendaraan pribadi. Ada yang tinggal menetap di Jakarta, ada yang hanya singgah untuk bekerja, ada pula yang melakukan wisata. Kunjungan wisatawan lokal dan mancanegara ke Jakarta mengalami peningkatan. Wisatawan mancanegara yang datang ke Jakarta 2,5 juta dan wisatawan lokal sebanyak 32,6 juta (Dinas Pariwisatan dan Kebudayaan DKI Jakarta, 2016).

Kehebatan kota Jakarta nampaknya tidak lantas membuat penduduknya bahagia. Tinggal di Jakarta justru membuat mereka mengalami tekanan yang berat. Bahkan tidak jarang menemui pendapat tentang Jakarta yang sudah tidak nyaman ditinggali. Kotanya besar dan hebat namun tidak bisa menutupi kelemahannya. Jakarta disebut-sebut sebagai salah satu kota dengan tingkat stres paling tinggi (Zipjet, 2017). Gubernur DKI Jakarta Anies Baswedan (2017) dalam rapat pembahasan kebijakan umum anggaran dan prioritas plafon anggaran sementara (KUA PPAS) mengungkapkan ada $20 \%$ warga Jakarta yang stres atau sekitar 2 juta penduduk. Berbagai faktor yang memengaruhi adalah kemacetan, ketidakstabilan dalam bidang ekonomi, belum ditambah dengan masalah di lingkungan kerja dan pribadi. Berbagai persoalan yang muncul menjadi beban bagi warga Jakarta yang harus dihadapi setiap hari. Nampaknya saat ini Jakarta menjadi kota yang "mengerikan" akibat masalah pelik di dalamnya.

Salah satu yang menjadi korban dari ketidak-ramahan kota Jakarta adalah pekerja. Stres adalah hal umum yang dialami oleh mereka. Berbagai faktor seperti beratnya tekanan pekerjaan, lingkungan yang tidak nyaman (bising, suhu, udara) maupun faktor dari individu itu sendiri membuat resiko stres menjadi tinggi. Walaupun banyak dari mereka yang tidak menyadari bahwa dirinya mengalami stres, namun berbagai gejala dari fisik (sakit kepala, sakit pinggang, otot tegang) dan psikis (sulit berkonsentrasi, sulit tidur, cepat marah) sering dialami oleh para pekerja. Dan banyak pula dari mereka yang mengalami stres mengabaikan hal tersebut dan pada akhirnya berujung ke stres kronis dan depresi sehingga membahayakan individu bahkan yang terparah bisa mengakibatkan bunuh diri.

Peran arsitektur nyatanya membawah pengaruh besar terhadap perasaan seseorang. Menurut Esther Sternberg (2009), lingkungan sekitar kita memengaruhi emosi dan emosi tersebut merespon dari cara arsitektur memengaruhi kesehatan. Dunia sekeliling kita memiliki terang dan gelap, suara dan bau, suhu dan sentuhan. Faktor-faktor tersebut masuk ke otak manusia melalui panca indera dan memicu pusat emosi di otak yang membuat kita bereaksi. Karenanya, arsitektur berpengaruh terhadap kesehatan dan kesembuhan manusia, termasuk kesembuhan secara psikologis.

Penulis melakukan survey terhadap 30 responden untuk mengetahui tingkat stres termasuk situasi lingkungan kerja mereka. Nyatanya, lingkungan kerja para responden tidak menunjukkan ruangan yang nyaman. Mereka bekerja dalam tempat yang kurang paparan sinar matahari, bising (suara telepon, printer, orang bicara), terkena AC terus-menerus, pekerjaan juga menuntut mereka untuk duduk dalam jangka waktu yang panjang. Rasanya tidak heran kalau pekerja menjadi stres akibat kondisi ruang yang tidak kondusif beserta masalah-masalah lainnya. Ketika stres menyerang produktivitas pekerja dapat menjadi rendah dan tidak mampu bekerja dengan baik.

Minimnya perhatian terhadap desain ruang membuat kehidupan sehari-hari menjadi tidak nyaman untuk dijalani. Padahal ruangan tersebut menjadi tempat dimana pekerja banyak menghabiskan waktunya. Pekerja seakan terkurung dalam ruangan empat sisi yang terasa seperti penjara dan membuatnya tidak nyaman. 
Berdasarkan pemaparan di atas, penulis tertarik untuk meciptakan arsitektur yang mampu mengayomi ke lima indera manusia di antaranya; penglihatan (sight), perasa (taste), peraba (touch), pendengaran (hear), dan penciuman (smell). Jurnal ini dikaji dengan buku The Eyes of The Skin dari Juhani Pallasmaa dengan maksud ingin membuat sebuah karya arsitektur yang mampu memerhatikan kualitas ruang dan pengaruhnya terhadap psikologis pengunjung, dalam hal ini adalah mereka yang mengalami stres bekerja dan membutuhkan tempat yang ramah dan bebas stres dalam rangka mengistirahatkan pikiran mereka dari tekanan pekerjaan sehari-hari.

\section{Tujuan Penulisan}

Tujuan penulisan ini adalah membuat tempat wisata yang mampu meredakan stres pengunjung dengan menstimulasi kelima indera manusia, membuat tempat wisata yang dapat membantu perkembangan kota Jakarta dalam bidang pariwisata dan ekonomi dan menekankan pentingnya suasana lingkungan sekitar yang nyaman bagi kedamaian psikologis manusia.

\section{KAJIAN LITERATUR}

\section{Definisi Pariwisata dan Tourism}

Menurut Undang-Undang Republik Indonesia Nomor 10 tahun 2009 Tentang Kepariwisataan, wisata adalah kegiatan perjalanan yang dilakukan oleh seseorang atau sekelompok orang dengan mengunjungi tempat tertentu untuk tujuan rekreasi, pengembangan pribadi, atau mempelajari keunikan daya tarik wisata yang dikunjungi dalam jangka waktu sementara.

Pada tahun 1905, Guyer-Feuler memperkenalkan definisi kata tourism (turisme/ kepariwisataan) untuk pertama kalinya. Guyer dan Feuler mengungkapkan bahwa tourism adalah "Sebuah fenomena unik di zaman modern yang bergantung pada bertambahnya kebutuhan manusia terhadap perubahan dan relaksasi, kesadaran atas indahnya alam dan seni dan kepercayaan akan alam yang mampu memberikan kebahagiaan pada umat manusia dan membantu negara dan masyarakat menjadi akrab karena perkembangan yang luar biasa dalam bidang perdagangan, industri, komunikasi dan transportasi. Dunia pariwisata berkembang dan membuatnya menjadi industri terbesar di dunia (Elizabeth, 2013).

\section{Definisi Rohani dan Spiritual}

Dalam Kamus Besar Bahasa Indonesia diterangkan bahwa definisi dari spiritual adalah hal yang berhubungan dengan atau bersifat kejiwaan (rohani, batin). Rohani sendiri adalah hal-hal yang berkaitan dengan roh. Rohani memiliki tiga persaman kata yaitu: batin, jiwa, psike, yang masing-masing memiliki arti sesuatu yang terdapat di dalam hati; sesuatu yang menyangkut jiwa (perasaan hati dan sebagainya), roh manusia (yang ada di dalam tubuh dan menyebabkan seseorang hidup), jiwa/ sukma/ rohani.

Spiritual berasal dari bahasa Latin, spiritus, yang berarti napas. Berdasarkan arti bahasa inggrisnya yang dimuat dalam kamus Cambridge (2007), spiritual adalah berkaitan dengan perasaan yang mendalam dan kepercayaan, terutama kepercayaan agama. Dalam kamus Oxford (2011) kata spiritual berarti berhubungan kepada jiwa manusia daripada fisiknya. Kesimpulan dari definisi kata rohani dan spiritual: Rohani adalah hal-hal yang berkaitan dengan jiwa, perasaan dan kepercayaan manusia.

\section{Architectural Tourism}

Peran arsitektur dalam dunia pariwisata memiliki kaitan yang erat, bahkan bergantung satu sama lain (Specht, 2014). Dalam pariwisata selalu ada kontribusi arsitektur di dalamnya seperti infrastruktur, akomodasi dan fasilitas sedangkan tanpa kegiatan pariwisata, arsitektur hanya menjadi objek yang mati. Penting bagi sebuah negara atau kota untuk memiliki karya 
arsitektur yang mampu dihargai di mata manusia untuk menunjang kegiatan pariwisata. Industri pariwisata dapat menjadi sumber ekonomi yang tinggi bagi wilayah yang bersangkutan. Pada era modern, arsitektur kontemporer berperan penting bagi kemajuan pariwisata. Arsitektur kontemporer selalu menyediakan inovasi dan transformasi yang membuat suatu wilayah dapat mengekspresikan dirinya.

Keberhasilan Frank Gehry dalam menghidupkan kembali kota Bilbao dengan cara merancang Museum Guggenheim membuat dunia arsitektur heran dengan efek yang timbul. Kota Bilbao pada akhir abad ke-20 adalah kota yang hampir mengalami kebangkrutan karena gerakan deindustrialisasi. Pemerintah menunjuk 3 arsitek yang berpartisipasi dalam sayembara untuk merancang bangunan yang bisa menolong kota Bilbao. Frank Gehry dengan lekuk-lekuk dari titanium menjadi pilihannya. Rancangannya dibuat dengan program komputer CATIA. Pada akhirnya bangunan Gehry dibuka pada tahun 1997 dan menjadi bangunan spektakuler pada masanya bahkan hingga sekarang. Arsitekturnya menawarkan sesuatu yang unik dan tidak biasa. Pada akhirnya persepsi pada kota Bilbao berubah dari kota industri yang hampir mati menjadi kota wisata modern.

Museum Bilbao Guggenheim menarik pengunjung karena (1) Unik: Bilbao Guggenheim menawarkan sesuatu yang tidak biasa. Jika bangunan seperti Bilbao Guggenheim dapat ditemukan di tempat-tempat lain, museum tersebut tidak akan berhasil menarik orang. Namun bangunan yang terlihat aneh tidak dapat dijumpai dimanapun pada saat itu. Desain bangunan menjadi pemikat utama turis untuk berkunjung bahkan tanpa mengetahui apa yang ada di dalamnya terlebih dahulu. Bentuknya seperti kapal karena terinsipirasi dari lokasinya yang ada di pinggir sungai. (2) Simbol: Saat orang mendengar Paris yang terlintas umumnya adalah menara Eiffel. Hal itu karena menara Eiffel sudah menjadi simbol bagi kota Paris. Tidak lengkap rasanya jika pergi ke Paris tanpa mengunjungi Eiffel. Dengan keunikannya, Guggenheim Museum berhasil menciptakan simbol untuk wilayahnya. (3) Program bangunan: Solomon R. Guggenheim adalah seorang kolektor seni. Saat itu Solomon R. Guggenheim Foundation di New York dikabarkan ingin memperluas kehadirannya di wilayah Eropa. Bilbao berhasil menyakinkan Guggenheim Foundation untuk meminjamkan nama dan barang-barang seni berkualitas tinggi mereka ke dalam museumnya.

\section{Experiencing Architecture}

Tidak cukup hanya melihat arsitektur; Anda harus mengalaminya (Rasumussen, 1964). Arsitektur mewujudukan bentuk bagi manusia, bentuk untuk ditinggali, bukan hanya sematamata dilihat dari luar.Seorang arsitek seperti produser teater, manusia yang mengatur hidup kita. Banyak keadaan yang membuat manusia bergantung pada cara arsitek mengaturnya. Ketika niatnya berhasil, arsitek akan berperan sebagai tuan rumah yang dengan sukses menyediakan tamu-tamunya pengalaman yang menyenangkan. Namun pekerjaannya sulit dalam beberapa alasan. Pertama, aktor-aktornya adalah orang biasa/ awam. la harus berhatihati terhadap cara aktor tersebut bertingkah secara alami; jika tidak semuanya akan gagal. Yang mungkin cocok dalam satu lingkungan budaya namun bisa salah jika ada di tempat lain. Apa yang cocok dalam satu generasi bisa menjadi aneh di kemudian hari ketika manusia sudah menemukan gaya dan kebiasaan baru.

Kedua, arsitek harus bisa melihat masa depan. Jadi bangunan yang dirancang bisa beradaptasi terhadap perubahan. Arsitek juga mempunyai kesamaan dengan tukang kebun lanskap. Semua orang mengerti fakta bahwa keberhasilan tukang kebun bergantung pada apakah pilihan tanamannya tumbuh subur. Tidak peduli secantik apapun konsepnya terhadap sebuah taman akan jadi kegagalan bila tidak tepat bila tanaman tidak ditempatkan pada lingkungan yang benar. Arsitek juga bekerja dengan mahkluk hidup- dengan manusia yang tidak dapat diperkirakan. Jika mereka tidak dapat berkembang dalam rumah tersebut maka keindahan bangunan akan jadi sa-sia. Salah satu bukti dari arsitektur yang baik adalah jika bangunan dapat digunakan sesuai yang direncanakan arsitek. 
Terakhir, adalah proses kreatif, bagaimana suatu bangunan terwujud. Arsitek bukan seorang pelukis dimana gambarnya merupakan hal personal. Tapi gambar arsitek nantinya akan menjadi instruksi bagi pekerja konstruksi yang membangun bangunannya.

\section{Kaitan Antara Kondisi Ruangan dan Panca Indera}

Dalam bukunya Place Advantege: Applied Psychology for Interior Architecture (2009), Sally Augustin mengatakan bahwa desain dari fisik tempat memengaruhi keadaan mental seseorang dalam ruang tersebut.

Tabel 1. Kondisi yang membuat manusia nyaman berdasarkan inderanya

\begin{tabular}{|c|c|}
\hline Indera & Kondisi \\
\hline $\begin{array}{l}\text { Penglihatan } \\
\text { (sight) }\end{array}$ & $\begin{array}{l}\text { Cahaya yang } \\
\text { bercorak, } \\
\text { permukaan dengan } \\
\text { lapisan matte, } \\
\text { bentuk yang } \\
\text { melengkung, } \\
\text { cahaya dengan } \\
\text { intensitas rendah }\end{array}$ \\
\hline $\begin{array}{l}\text { Perasa } \\
\text { (taste) }\end{array}$ & $\begin{array}{c}\text { Warna-warna yang } \\
\text { dingin seperti biru, } \\
\text { corak-corak yang } \\
\text { sistematis (natural } \\
\text { fractals) }\end{array}$ \\
\hline $\begin{array}{l}\text { Peraba } \\
\text { (touch) }\end{array}$ & $\begin{array}{l}\text { Menyentuh } \\
\text { permukaan yang } \\
\text { lembut, } \\
\text { temperatur yang } \\
\text { sedikit hangat }\end{array}$ \\
\hline $\begin{array}{l}\text { Pendengaran } \\
\text { (hear) }\end{array}$ & $\begin{array}{l}\text { Suara alam seperti } \\
\text { air dan dedaunan }\end{array}$ \\
\hline $\begin{array}{l}\text { Penciuman } \\
\text { (smell) }\end{array}$ & $\begin{array}{c}\text { Menghirup aroma } \\
\text { yang memberi efek } \\
\text { relaksasi seperti } \\
\text { lavender, vanilla, } \\
\text { cendana, } \\
\text { chamomile }\end{array}$ \\
\hline
\end{tabular}

Sumber: Data Olahan Pribadi, 2018

\section{Kaitan Antara Arsitektur dan Panca Indera}

Indera adalah hal penting untuk pengalaman sehari-hari karena dapat memberikan kita pengetahuan tentang dunia di sekitar kita dan, melalui struktur dan cara kita menggunakannya (Rodaway, 1994: 3). Dalam arsitektur seringkali manusia hanya mementingkan mengenai tampak dan keindahan secara visual. Padahal manusia memiliki indera lain selain mata yang perlu dimanjakan. Seperti yang dikatakan oleh Juhani Pallasmaa (1996: 45), arsitektur adalah pengalaman multisensori.

Plato mengatakan penglihatan adalah hadiah terhebat bagi manusia. Penglihatan disini berarti memuaskan penglihatan manusia dengan keindahan rancangan arsitektur. Lain halnya dengan lidah yang menjadi alat untuk mengecap, dalam arsitektur perasa (taste) adalah sesuatu yang 'enak' dilihat pada mata seperti warna dan material suatu objek. Peraba (touch) berkaitan dengan suhu, cahaya matahari, tekstur, udara, dan getaran. Keheningan atau ketenangan adalah salah satu pengalaman menyenangkan untuk pendengaran dalam arsitektur. Terakhir ada penciuman (smell), aroma adalah unsur penting untuk membentuk 
identitas suatu ruang. Seperti bau rumah sakit yang sudah melekat dalam otak manusia sehingga hanya dengan mencium aromanya tersebut orang bisa mengenali tempat yang dimaksud (Pallasmaa, 1996).

\section{DISKUSI DAN HASIL Informasi Tapak}

Jakarta Selatan adalah salah satu bagian kota administratif yang bisa dibilang menjadi tempat favorit orang-orang untuk bergaul. Banyak sekali tempat-tempat wisata yang berdiri disini. Sebut saja Kebun Binatang Ragunan, Setu Babakan, dan masih banyak lagi. Di samping itu banyak juga tempat-tempat nongkrong kekinian yang menjadi incaran anak-anak muda untuk menapakkan kakinya.

Tapak terpilih berlokasi di Jl. Kemang Selatan, Bangka, Mampang Prapatan, Jakarta Selatan dengan luas area sebesar $3.200 \mathrm{~m}^{2}$ (Lihat gambar 1). Ketentuan peraturan adalah sebagai berikut: KDB 30\%, KLB 0.9, KB 3, KDH 45\%, dan KTB 0. Pada kondisi eksisting, tapak memiliki batas utara berupa rumah tingkat dua, batas barat adalah pertokoan, batas Selatan adalah The Habibie Center, dan batas Timur adalah Dia Lo Gue Art Space. Peraturan fungsi bangunan adalah perumahan namun pada kenyataannya saat ini bangunan yang ada di deretan tapak sudah beralih fungsi peruntukannya menjadi komersial.

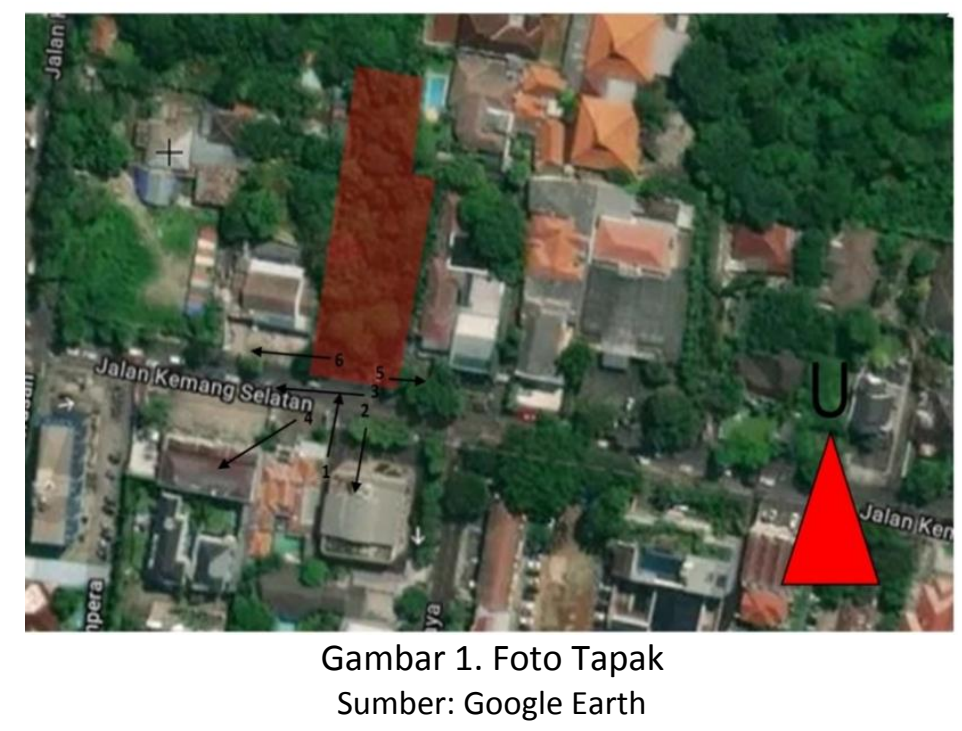

\section{SWOT Tapak}

Lokasi tapak yang dipilih berada di kawasan Kemang, Jakarta Selatan. Daerah ini identik sebagai tempat yang elit. Kemang memiliki magnet yang kuat untuk orang-orang Jakarta dengan lengkapnya fasilitas yang ada. Hal ini menjadi kekuatan dari tapak terpilih. Deretan bangunan menawarkan restoran dan cafe hits yang selalu bersifat instagramable, dimana kehidupan zaman modern tidak lagi dapat dipisahkan dari yang namanya media sosial. Kemang menjadi tempat berkumpulnya anak-anak muda, dewasa dan keluarga. Dengan stereotipe 'gaul', Kemang selalu menjadi pilihan untuk dikunjungi dari berbagai kalangan.

Kelemahan dari lokasi ini adalah aksesibilitas yang sulit bagi pengguna transportasi umum berupa Transjakarta. Untuk mencapai lokasi tapak bagi pengguna kendaraan umum, pengunjung harus turun di halte terdekat yaitu halte Duren Tiga (lihat gambar 2). Dari halte, pengunjung bisa menggunakan transportasi online atau konvensional.

Five Senses Experience Space adalah sebuah tempat yang menawarkan pengalaman baru bagi pengunjung. Berbeda dengan art space yang merajalela di daerah Kemang, Five Senses Experience Space memberikan pengalaman melalui ruang dan perjalanan di dalamnya 
sehingga hal ini bisa menjadi peluang yang baik karena tempat wisata ini menawarkan sesuatu yang berbeda dari yang biasa dijumpai di sekitaran Kemang.

Ancaman yang ada di lokasi ini adalah kesulitan akses bagi kendaraan jika hujan karena gang-gang terdekat untuk mencapai tapak biasanya mengalami banjir. Jika banjir, pengunjung harus menempuh jalan yang lebih jauh untuk mencapai lokasi.

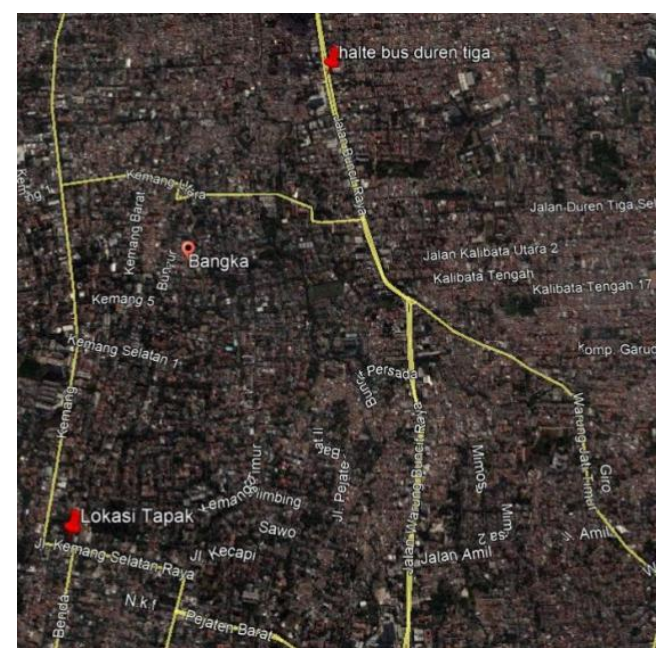

Gambar 2. Jarak dari Halte Bus Terdekat Menuju Lokasi Tapak Sumber: Google Earth

\section{Hasil Desain}

\section{Program Kegiatan}

Dengan mengambil kesimpulan dari kajian teori, dibuatlah tiga program utama yang akan dinikmati pengunjung. Setiap ruangannya memberikan pengalaman kepada indera yang berbeda. Berikut adalah grafik indera yang digunakan pada setiap ruang:

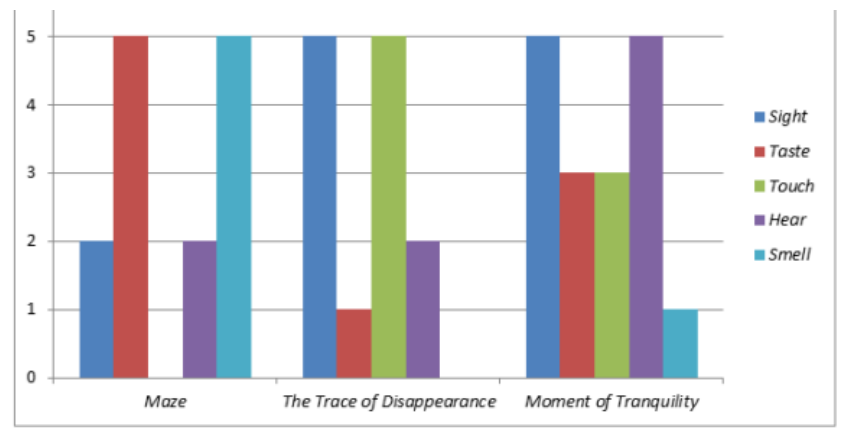

Gambar 3. Grafik Indera yang Digunakan Pada Setiap Ruang Sumber: Data Olahan Pribadi, 2018

\section{Pembentukan Massa Bangunan}

Tapak memiliki bentuk memanjang (1). Massa bangunan dibentuk berupa persegi panjang (2). Lalu bentuk tersebut dipotong di bagian sisi kanannya mengikuti bentuk tapak (3). Karena dalam peraturan bangunan tidak diijinkan adanya basement, parkir kendaraan harus diletakkan di lantai satu. Sehingga untuk menyiasati hal tersebut bangunan diangkat di bagian tengah sebagai tempat parkir (4). Parkir diletakkan di tengah bangunan karena bagian depan diutamakan bagi pejalan kaki. Di bagian depan terdapat taman yang dibuka untuk publik yang diperuntukkan bagi semua orang baik yang ingin menikmati tempat wisata atau hanya sekedar jalan-jalan. Untuk akses masuk kendaraan terdapat di sisi kanan sedangkan akses keluar ada di bagian kiri (lihat gambar 5.2). Kemudian di atas tempat parkir dibuat courtyard yang digunakan 
sebagai ruang untuk program Five Senses Experince Space berupa kolam (5). Bangunan kemudian ditambah sirkulasi berupa tangga balkon untuk keluar dari bangunan yang memiliki serangkain perjalanan (6). Massa bangunan akhirnya terbentuk dengan ketinggian bangunan sejumlah 3 lantai (7) (lihat gambar 4).

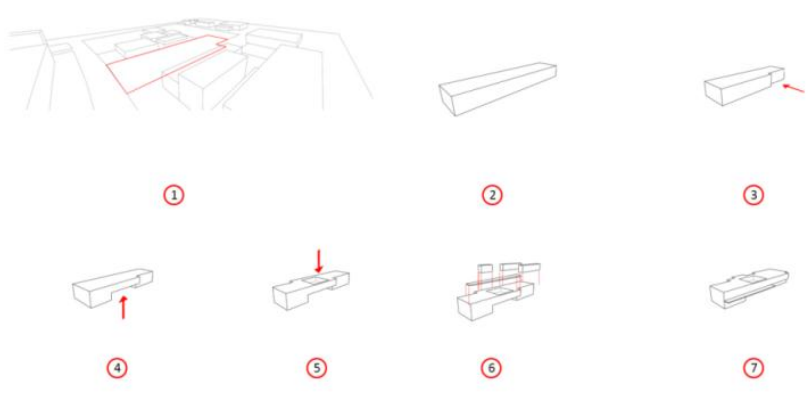

Gambar 4. Pembentukkan Massa Bangunan

Sumber: Data Olahan Pribadi, 2018

\section{Zoning}

Zoning bangunan dipisahkan secara letak. Bagian depan diperuntukkan bagi publik dimana terdapat lobi pada lantai satu, ruang tunggu bagi pengunjung pada lantai dua dan kafe di lantai tiga yang bisa diakses dengan lift atau tangga. Untuk ruang experiential ada di bagian tengah yang dimulai dari lantai dua dengan ruang Stuck in a Maze dan Moment of Tranquility. Bagian servis diletakkan di bagian belakang bangunan bersamaan dengan kantor pada lantai satu sehingga tidak mengganggu sirkulasi pengunjung. Pada lantai dua dan tiga (di atas kantor) merupakan ruang maze dan The Trace of Disapperance yang menyambung ke ruang Moment of Tranquility (lihat gambar 5).

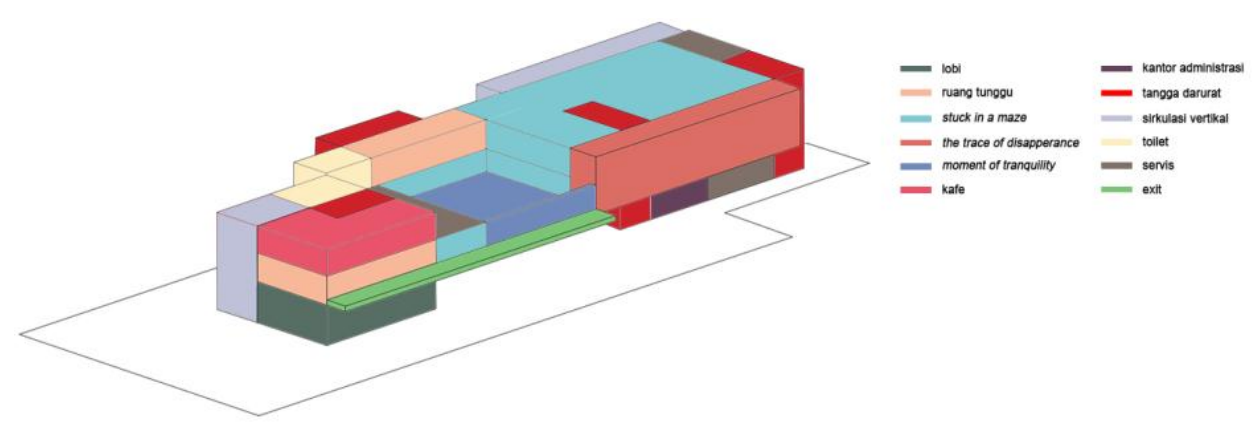

Gambar 5. Zoning Bangunan

Sumber: Data Olahan Pribadi, 2018

\section{Sirkulasi}

Sirkulasi adalah hal yang penting dalam proses perancangan Five Senses Experience Space. Di dalam bangunan ini pengunjung akan melalui perjalanan di dalam ruangan maze yang gelap. Di dalam maze yang gelap pengunjung akan dituntun menuju jalan keluar melalui aroma yang diletakkan pada titik-titik tertentu. Aroma disebarkan dengan menggunakan konsep aroma terapi. Fire pit digunakan untuk mebakar minyak aroma terapi yang bisa menimbulkan efek relaksasi bagi pengunjung untuk meredakan stres. Sehingga walau tersesat di dalam maze, pengunjung tetap dapat merasa rileks melalui stimulasi penciuman.

Sumber aroma dari bangunan ini ada di tiga titik. Ketiga titik ini menggunakan fire pit dan aroma terapi yang dituang dalam kuali dan dibakar di atas fire pit. Aroma akan tercium oleh pengunjung yang sedang berjalan mencari jalan keluar. Di dalam maze yang gelap pengunjung akan dituntun menuju jalan keluar melalui aroma yang diletakkan pada titik-titik tertentu. 
Aroma disebarkan dengan menggunakan konsep aroma terapi. Fire pit digunakan untuk mebakar minyak aroma terapi yang bisa menimbulkan efek relaksasi bagi pengunjung untuk meredakan stres. Sehingga walau tersesat di dalam maze, pengunjung tetap dapat merasa rileks melalui stimulasi penciuman ini.

Titik akhir perjalanan ada di dalam ruang Moment of Tranquility. Indera pendengaran berperan dalam ruangan ini. Suara air yang menenangkan akan membuat manusia merasa rileks dan reda dari stress (lihat gambar 6).

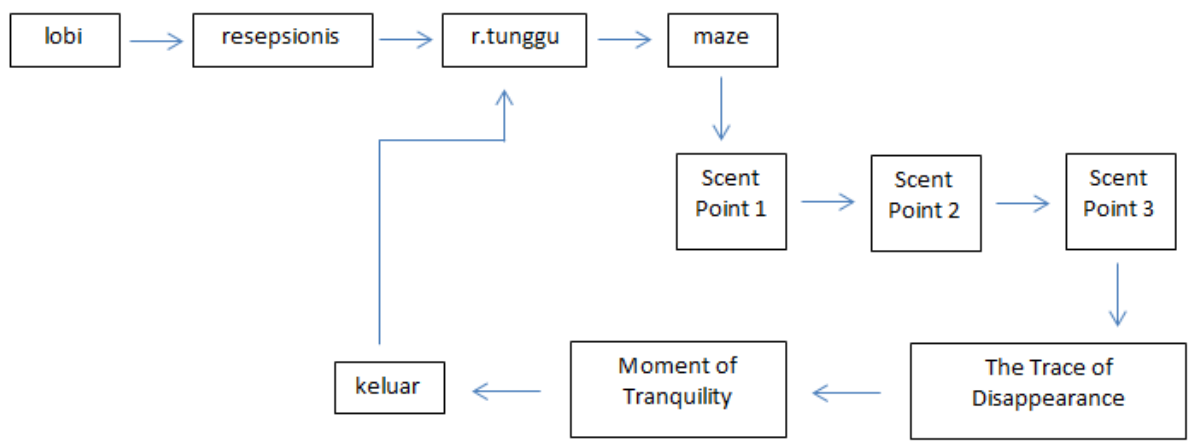

Gambar 6. Alur Sirkulasi Pengunjung

Sumber: Data Olahan Pribadi, 2018

\section{Eksterior}

Eksterior didesain dengan maksud memberikan kesan menenangkan bahkan dari hanya dengan melihat bangunannya dari luar. Salah satu caranya adalah dengan menaruh satu pohon peneduh yang besar sebagai fokus utama bagi visual orang-orang yang melewati bangunan. Di bawah pohon peneduh tersebut adalah tempat duduk berbentuk lingkaran dimana pengunjung dapat duduk-duduk santai menikmati pemandangan hijau dari taman (lihat gambar 7). Untuk mengaksesnya pengunjung dapat melewati jalur khusus pedestrian yang mengarah ke lobi. Desain bangunan menyerupai rumah tinggal. Hal ini karena rumah adalah tempat yang nyaman bagi manusia sehingga ketika orang melihat bangunan ini dapat memberikan efek psikologis yang menenangkan layaknya pulang ke rumah.

Desain bangunan mengusung tema kesederhanaan. Karena itu material yang dipilih adalah perpaduan antara kayu dan batu bata. Kedua material tersebut memberikan kesan sederhana pada bangunan. Lapisan kayu digunakan untuk menutupi bagian dinding tembok. Batu bata hanya digunakan untuk lobi, ruang tunggu dan kafe. Sususan batu bata memiliki rongga sehingga ketiga ruangan tersebut tidak memerlukan pengudaraan buatan melainkan alami. Selain itu karena bangunan tampak depan menghadap utara, cahaya matahari yang baik dapat masuk dan menyinari ruangan. Di bagian kanan bangunan ada pemakaian material metal sebagai dinding. Material ini diberi lubang-lubang dengan pola lingkaran yang berukuran besar dan semakin mengecil di ujungnya. Material ini digunakan untuk ruangan The Trace of Disappearance yang menggunakan konsep cahaya untuk pengalaman ruang (lihat gambar 8 ).

\section{Interior}

Pengunjung pertama kali akan masuk ke ruangan maze. Maze diibaratkan menjadi rutinitas orang yang berulang-ulang. Saat lelah perasaan ingin berhenti sejenak dan "menghilang" bisa muncul dalam benak manusia. Ruangan ini dibuat gelap agar indera penglihatan menurun sehingga indera lainnya akan meningkat (dalam hal ini indera penciuman yang ingin ditingkatkan). Sumber cahaya diperoleh dari kotak maze yang di lapisi dengan light strip pada sisi-sisinya sehingga membiaskan cahaya berdasarkan warna lampunya (lihat gambar 9). Kotak maze ini berupaya untuk meningkatkan indera perasa bagi pengunjung lewat warna-warni cahaya. 
Langit-langit ruangan maze dibuat tidak terlalu tinggi yaitu 2,7 meter dengan tinggi maze 2,5 meter (ada jarak $20 \mathrm{~cm}$ untuk sirkulasi aroma). Ketinggian langit-langit ini dimaksudkan agar aroma dari scent point tidak menyebar terlalu jauh atau tinggi yang bisa mengakibatkan aroma tersebut hilang sebelum tercium oleh pengunjung (lihat gambar 7). Berikutnya di ruangan The Trace of Disappearance merupakan ruang dengan lebar 2,5 meter berupa tangga yang membawa pengunjung turun dari lantai tiga ke lantai dua menuju ruangan Moment of Tranquility (lihat gambar 10). Ketika pengunjung menuruni tangga, lubang-lubang cahaya akan semakin mengecil hingga pada akhirnya ketika selesai menuruni tangga pengunjung akan merasakan kegelapan sejenak karena sisi dinding dibuat seutuhnya tertutup. Dari ruangan ini pengunjung juga bisa melihat air terjun buatan yang ada di Moment of Tranquility. Air terjun diletakkan sesuai aksis dari pintu ruangan The Trace of Disappeance.

Ruangan Moment of Tranquility adalah ruangan terbuka dengan air terjun buatan sebagai fokus utamanya. Selain inera penglihatan, indera pendengaran adalah hal utama yang ingin ditingkatkan. Untuk menikmati air terjun ini dengan tenang dibuat ruangan semi terbuka dengan bentuk kubah. Ritme dari kubah ini juga bermaksud untuk memberikan efek relaksasi secara visual (lihat gambar 11).

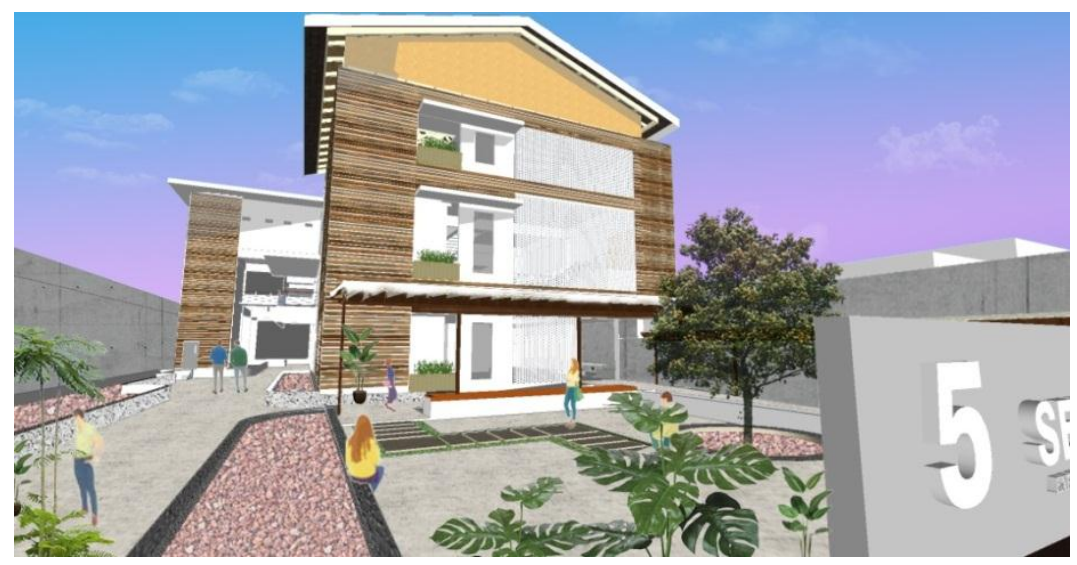

Gambar 7. Eksterior Bangunan

Sumber: Data Olahan Pribadi, 2018

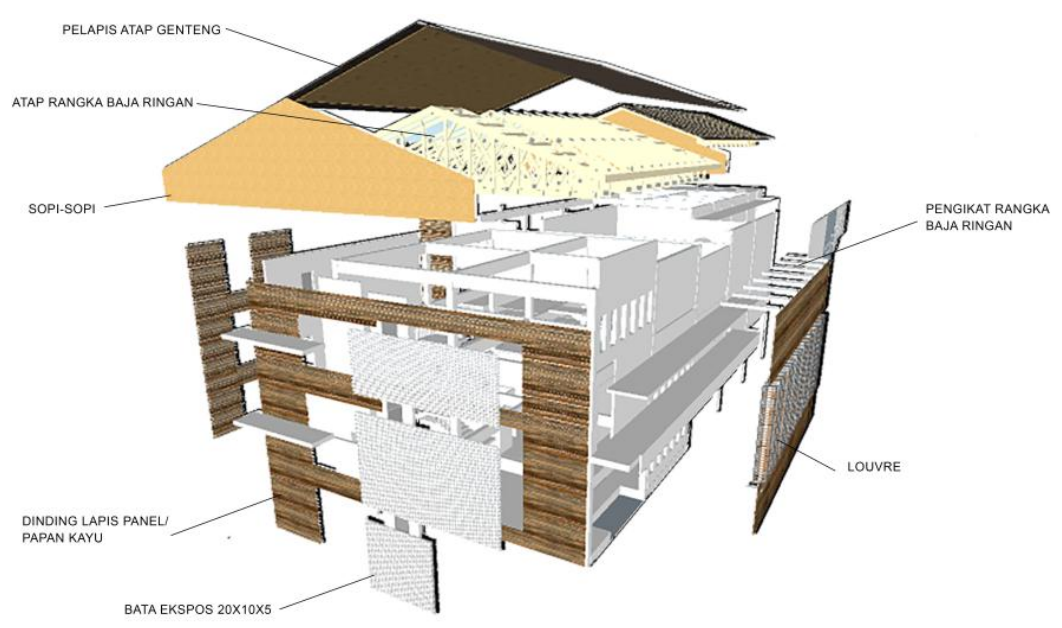

Gambar 8. Aksonometri Material Sumber: Data Olahan Pribadi, 2018 


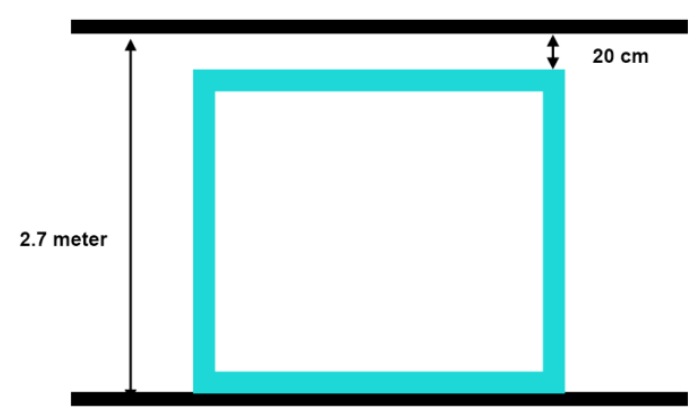

Gambar 9. Kotak Maze

Sumber: Data Olahan Pribadi, 2018

\section{KESIMPULAN DAN SARAN}

Panca indera adalah alat yang digunakan manusia untuk mempelajari dan mengenal dunia di sekitarnya. Ketika panca indera tidak bisa lagi digunakan, maka manusia tidak dapat lagi merasakan lingkungan sekitarnya secara utuh. Dengan dibuatnya Five Senses Experience Space, penulis ingin membuat orang-orang yang terjebak dalam hiruk-pikuk kota Jakarta sadar terhadap pentingnya indera manusia dalam kehidupan sehari-hari. Jika lingkungan hidup tidak nyaman maka manusia akan merasa tidak nyaman juga. Sebaliknya, jika lingkungan hidup nyaman, manusia pun akan merasa nyaman secara fisik dan psikologis. Perkembangan penduduk kota Jakarta nampaknya akan sulit untuk dikontrol mengingat kehidupan dan fasilitas urban yang memikat banyak orang di kota-kota lain. Tapi kita dapat mengontrol perilaku dan kebiasaan diri untuk menjaga Jakarta sehingga kota ini dapat menjadi tempat bernaung yang nyaman bagi kita dan generasi selanjutnya.

\section{UCAPAN TERIMA KASIH}

Penulis mengucapkan terima kasih kepada Universitas Tarumanagara yang telah memberikan dukungan berupa fasilitas dan kepada pihak-pihak lain yang membantu dalam pembuatan jurnal ini sehingga dapat selesai.

\section{REFERENSI}

Databoks. (2019, Januari 20). Retrieved Juli 14, 2018, from databoks.katadata:

https://databoks.katadata.co.id/datapublish/2016/09/08/26-persen-warga-jakarta-bekerjasebagai-karyawan

APPA. (n.d.). www.apa.org. Retrieved juli 14, 2018, from www.apa.org/helpcenter/stresskinds.aspx

Pallasma, J. (1996). The Eyes of The Skin. New York: Wiley Academy.

Rasmussen, S. E. (1962). Experiencing Architecture. Cambridge: MIT Press LTD.

Riana, F. (2017, November 4). Tempo. Retrieved Juli 13, 2018, from Tempo: https://metro.tempo.co/read/1030698/anies-sebut-ada-2-juta-orang-stres-di-dki

Rodaway, P. (1994). Sensuous Geography: Body, Sense and Place. London: Taylor \& Francis LTD.

Sally Augustin, N. F. (2009). Place Advantage: Applied Psychology for Interior Architecture. New York: Wiley Academy.

Specht, J. (2014). Architectural Tourism. Amerika Serikat: Spring Gabler.

Sternberg, H. M. (2009). Healing Spaces: The Science of Place and Well-Being. Cambridge: Harvard University Press.

Syahid, A. R. (2015, Juni 25). Studi Pariwisata. Retrieved Juli 13, 2018, from Studi Pariwisata: https://studipariwisata.com/serba-serbi/arti-kata-tourism-dan-pariwisata-ternyata-tidaksama/ 